\title{
ISOLATION AND CHARACTERIZATION OF MDR BACTERIA FROM IN VITRO CULTURE OF BACOPA MONNIERA AND SUPPLEMENTATION OF NATURAL EXTRACTS TO CONTROL BACTERIAL CONTAMINATION
}

\author{
YASH SHARMA1, MANISH BHARDWAJ1 ${ }^{1}$, ANSHITA NAGAR ${ }^{2}$, NEETA BHAGAT ${ }^{*}$ \\ ${ }^{1}$ Amity Institute of Biotechnology, Amity University, Noida, Uttar Pradesh, India, ${ }^{2}$ Helix BioGenesis Pvt. Ltd., Noida, India \\ Email: nbhagat@amity.edu
}

Received: 21 Jun 2016 Revised and Accepted: 09 Sep 2016

\begin{abstract}
Objective: The purpose of the present study was to isolate and characterize bacterial contamination from in vitro culture of Bacopa monniera callus culture.

Methods: The two selected isolates (1 and 2) were identified by morphological, biochemical and molecular (16S rRNA gene sequencing) methods. Beside this antibiotic resistance was also determined.

Results: The isolates were identified as closely related to Enterobacter cloacae (KU350623) (Isolate 1) and Myroides odoratimimus (KU382740) (Isolate 2). The isolate 1 and 2 were found to be resistant to streptomycin $(25 \mathrm{mcg})$, dapsone $(10 \mathrm{mcg})$, erythromycin $(15 \mathrm{mcg})$, chloroamphenicol $(25 \mathrm{mcg})$ and ampicillin $(10 \mathrm{mcg})$. Supplementation of the natural extract was tested to control the contamination due to these multi drug resistant bacteria. Aqueous and alcoholic leaf extracts of Azadirachta indica was added to plant tissue culture media i.e. MS media in order to control contamination.
\end{abstract}

Conclusion: The present studies suggest using natural extracts supplementation as a promising strategy to control the in vitro bacterial contamination in plant tissue culture.

Keywords: Contamination, Bacopa monniera, Gram-negative microorganism, 16S rDNA

(c) 2016 The Authors. Published by Innovare Academic Sciences Pvt Ltd. This is an open access article under the CC BY license (http://creativecommons.org/licenses/by/4. 0/) DOI: http://dx.doi.org/10.22159/ijpps.2016v8i11.13593

\section{INTRODUCTION}

Medicinal plants are the most important source of life-saving drugs all over the world. The biotechnology offers promising methods to select multiply and conserve the critical germplasm of medicinal plants. Plant tissue culture techniques offer an integrated approach for the production of standardized quality phytopharmaceutical through mass-production of consistent plant material for physiological characterization and analysis of active ingredients [1]. Tissue culture is a preferable method for rapid multiplication of healthy medicinal plants. However, microbial contamination is considered to be as one of the most serious problems in tissue culture of the medicinal plant [2]. Contamination with microorganisms is the most important reason for losses during in vitro culture of plants. Such microorganisms include viruses, bacteria, yeast, fungi, etc. These microbes compete adversely with plant tissue cultures for nutrients $[3,4]$. The presence of these microbes not only causes increased culture mortality but can also lead to abnormal growth, reduced shoot proliferation, reduced rooting and tissue necrosis $[5,6]$. Contamination in plant tissue cell cultures originates from two sources i.e. since the tissue used to initiate the culture, and from the laboratory environment [7]. Contaminants transferred in or on the plant material include plant pathogens and environmental microorganisms. Most epiphytes are controlled by surface sterilants, however, these do not assure elimination of endophytic organisms [2]. Endophytes may be intercellular pathogens, as well as opportunistic and adapted colonizers originating from the environment; or intracellular viruses, viroids, and bacteria. Several plants and related environmental factors such as plant species, age, explant source and prevailing weather condition contribute to in vitro cultures [8]. Despite the best timing and selection efforts it is almost impossible to eliminate contamination from in vitro grown plants. Failure of sterile technique or equipment malfunction renders aseptic cultures contaminated in the laboratory. Laboratory contamination is caused by plant-associated, environmental, and human-associated bacteria, yeasts, and microarthropods. Most microbial contaminants are expressed (i.e. Grow) on plant tissue culture media, but some may be latent. Detection, and identification is a prerequisite for the control and elimination of laboratory contamination. Conventional disinfection methods like sodium hypochlorite, mercuric chloride fails to give satisfactory results as the explants are damaged by their overuse [9]. Antibiotics incorporated in the culture media or pretreatment of explants can eliminate internal contamination $[10,11]$.

Bacopa monniera, commonly known as Brahmi belongs to the family of Scrophulariaceae. It is native to India, Nepal, Sri Lanka, China, Taiwan and Vietnam, found in wetlands throughout the Indian subcontinent in damp and marshy areas in tropical regions. It is known as medhyarasayana, a drug which is used to improve the memory and intellect (medhya) [12]. It is a small creeping herb with branches, small leaves, light purple and white flowers [13]. Extracts of Bacopa monniera contain $25 \%$ bacoside which was demonstrated to have an antianxiety effect on a rat without any side effects [14]. An active constituent of Bacopa monniera i.e. hersaponin Protections against seizures in mice and is used for the treatment of epilepsy [15]. An aqueous extract of Bacopa reduced nicotin-induced lipid peroxidation and conferred gene protection in Swiss mice [16]. As far as the Azadirachta indica is concerned, it is commonly known as neem tree. It's a medicinal plant where each parts of its consist of different secondary metabolites. It is established in many scientific studies that neem seeds contain chemical compounds to control more than 100 species of insects and microorganism [17]. Three different forms of neem products such as aqueous extract, seed oil, seed powder have been used extensively against microorganisms. Neem leaves are reported as the main sources of the active compounds obtainable from the plant [18]. Also, we know that major source of contamination in in vitro culture facilities are airborne. Neem leaves smoke treatment has been reported to control airborne bacterial growth on the bacterial agar medium plates [19]. Also, neem is easily available and highly cost effective. Considering these properties neem extract was used to study it's antimicrobial effectiveness in Bacopa callus culture.

The main objective of our study was to isolate, identify and characterize the gram-negative bacteria contaminating the in vitro culture of Bacopa monniera callus and also antimicrobial activities of 
an aqueous and methanolic extract of leaf of Azadirachta indica were studied to control contamination.

\section{MATERIALS AND METHODS}

\section{Plant tissue culture of callus (Bacopa monniera)}

The leaves of Bacopa monniera plants, was taken as explants, were collected from the plant tissue culture lab of Helix BioGenesis Pvt. Ltd., Noida, Uttar Pradesh, India. Leaves were washed in soapy water, and the surface was sterilized in $0.1 \%(\mathrm{v} / \mathrm{v})$ Tween 20 for $15 \mathrm{~min}$, and then rinsed using $0.1 \% \mathrm{HgCl}_{2}$ for 5 min followed by rinsing them five times with double distilled water. These were implanted vertically on Murashige and Skoog media (MS media), which was prepared with specific concentrations of 6-benzylaminopurine (BAP), kinetin (Kn) (1.0$5.0 \mathrm{mg} / \mathrm{l}$ ) singly or in combination were used for shoot proliferation. The media containing $3 \%$ sucrose was solidified with $8 \mathrm{gl}^{-1}$ agar. The $\mathrm{pH}$ of the media was maintained to $5.8 \pm 0.02$. All the experiments were performed in aseptic conditions. The in vitro cultures were incubated under controlled conditions of temperature $\left(25 \pm 2{ }^{\circ} \mathrm{C}\right)$, light $(2000-2500$ lux for $16 \mathrm{hr} / \mathrm{d}$ provided by fluorescent tubes) and $60-70 \%$ humidity [20]. Callus was observed for development of contamination.

\section{Morphological and biochemical characterization of the} bacterial isolates

Loopful of contamination developed on callus was cultured on EMB agar plates aseptically. The inoculated plates were incubated at $37 \pm 0.5^{\circ} \mathrm{C}$ for $24 \mathrm{~h}$. Isolated colonies (Isolate 1 and 2) were selected and subcultured on EMB plates. These colonies were characterized morphologically and biochemical tests (Catalase, Coagulase, Citrate, Indole, Nitrite reduction, Urease, Triple sugar iron agar (TSI) and MR-VP) were carried out to authenticate their identity [21].

\section{Molecular characterization (16S rRNA gene amplification)}

Genomic DNA was extracted from the bacterial culture [22] and 16S rDNA was amplified by using the universal bacterial 16S rDNA primers, $\mathrm{F}$ (5'-AGHGTBTGHTCMTGNCTCAS-3) and $\mathrm{R}$ (5'TRCGGYTMCCTTGTWHCGACTH-3'). PCR was performed with $50 \mu \mathrm{l}$ reaction mixture containing $1 \mu \mathrm{l}(10 \mathrm{ng})$ of DNA extract as a template, each primer at a concentration of 10 picomole/ $\mu \mathrm{l}, 25 \mathrm{mmol} \mathrm{MgCl}_{2}$ and dNTPs at a concentration of $2 \mathrm{mmol}, 1.5 \mathrm{U}$ of Taq polymerase and buffer as recommended by the manufacturer. After the initial denaturation for $5 \mathrm{~min}$ at $94^{\circ} \mathrm{C}$, there were 30 cycles of denaturation at $94^{\circ} \mathrm{C}$ for $30 \mathrm{sec}$, annealing at $54^{\circ} \mathrm{C}$ for $1 \mathrm{~min}$, extension at $72^{\circ} \mathrm{C}$ for $1 \mathrm{~min}$ and $30 \mathrm{sec}$ and a final extension at $72{ }^{\circ} \mathrm{C}$ for $10 \mathrm{~min}$. PCR products were analyzed by $1.5 \% \mathrm{w} / \mathrm{v}$ agarose gel electrophoresis in $1 \mathrm{x}$ TAE buffer with ethidium bromide $(0.5 \mu \mathrm{g} / \mathrm{ml})$. PCR product was sequenced by capillary sequencing using ABi 3500 Genetic Analyzer machine as per manufacturer's information. The 16S rRNA gene sequences were compared with known sequences in the GenBank database to identify the most similar sequence alignment. Sequences were matched with previously published bacterial 16S rRNA gene sequences in the NCBI databases using ADVANCED BLAST [23]. Based on the scoring index, the most similar sequences were aligned with the sequences of other representative bacterial 16S rDNA regions by using multiple alignment software program Clustal W. Phylogenetic tree was constructed using the Neighbor-Joining method by Phylogeny. fr (http://www.phylogeny. fr/simple_phylogeny. cgi) [24]. The sequence was submitted to NCBI-GenBank database.

\section{Antimicrobial sensitivity test}

The antibiotic susceptibility testing was carried out by using disc diffusion method [25]. The antibiotic used were streptomycin $(25$ $\mathrm{mcg}$ ), cefotaxime (30 mcg), gentamicin (10 $\mathrm{mcg})$, amphotericin b $(25$ $\mathrm{mcg})$, amoxicillin $(20 \mathrm{mcg})$, dapsone $(10 \mathrm{mcg})$, erythromycin $(15$ $\mathrm{mcg}$ ), chloramphenicol (25 mcg), ampicillin (10 mcg), rifampicin (10 $\mathrm{mcg})$, tricarcillincalvulanic acid $(10 \mathrm{mcg})$, aztreonam $(30 \mathrm{mcg})$, imipenem $(10 \mathrm{mcg})$ and meropenem $(10 \mathrm{mcg})$. The standardization of the inoculum (Isolate 1 and Isolate 2) was done. A loopful of a bacterial colony was picked and added in $3.0 \mathrm{ml}$ of normal saline. The turbidity was adjusted to the turbidity of barium sulphate $(0.5$ McFarland standard). A cotton swab was dipped into the suspension, and the swab was pressed against the side of the bottle to remove excess fluid. The inoculated swab was then streaked across the surface of the nutrient agar and allowed to dry for five minutes after which sterile forceps were used to carefully remove the antibiotic discs from its pack and gently pressed onto the agar surface. The plates were finally incubated at $37^{\circ} \mathrm{C}$ for $24 \mathrm{~h}$. After the incubation period, the diameter of the zone of inhibition (clearance) was measured. The results were recorded and interpreted on the basis of National Committee for Clinical Laboratory Standards or NCCLS.

\section{Preparation of extracts}

The fresh and healthy leaves of Azadirachta indica (Neem) were collected from IARI, New Delhi. Leaves of Azadirachta indica were identified by Dr. Ravindra Kumar, Assistant Professor, Department of Botany, Hindu College, Delhi University, Delhi. India. Aqueous and alcoholic extracts of leaves of Azadirachta indica were prepared by standardized protocol $[1,17]$. The aqueous extract was prepared by dissolving $5 \mathrm{~g}$ of washed, dried and crushed leaves in $50 \mathrm{ml}$ of distilled water, whereas alcoholic extract was prepared by the dissolving same amount of leaves in methanol solvent. Extracts were placed on a water bath for $30 \mathrm{~min}$ followed by shaking in an incubator at $250 \mathrm{rpm}$ for $48 \mathrm{~h}$. After shaking, they were filtered twice. The filtered aqueous extracts were stored at $4{ }^{\circ} \mathrm{C}$ whereas alcoholic extracts were evaporated to dryness $[1,17]$.

\section{Treatment of MS media with the supplementation of extracts to} control contamination in callus

Plant tissue culture MS media was supplemented with a specific concentration of filter sterilized aqueous and alcoholic extracts of leaves of Azadirachta indica (1 mg/ml). The media containing 3\% sucrose was solidified with $8 \mathrm{gl}^{-1}$ agar. The $\mathrm{pH}$ of media was maintained to $5.8 \pm 0.02$. Media was sterilized by autoclaving at $121{ }^{\circ} \mathrm{C}$ and 15 psi for $20 \mathrm{~min}$. MS media was supplemented with a specific concentration of filter sterilized aqueous and alcoholic extracts of leaves of Azadirachta indica $(1 \mathrm{mg} / \mathrm{ml})$. Bacterial contaminants Isolate 1 and 2 were inoculated into the plant tissue culture medium. The excised callus of Brahmi was inoculated on MS media supplemented with aqueous and alcoholic extracts of leaves of Azadirachta indica. Growths of callus in different flasks were monitored. The observation for bacterial growth was monitored for $20 \mathrm{~d}$ of incubation. Experimental setup consisted of 7 groups. Group I included control MS media without any extract supplementation. Group II was MS media inoculated with Isolate 1 without any supplementation. Group III included culture flask with MS media supplemented with aqueous extracts of leaves of Azadirachta indica $(1 \mathrm{mg} / \mathrm{ml})+$ +inoculums of Isolate 1. Group IV included flask with MS media supplemented with methanolic extracts of leaves of Azadirachta indica+Isolate 1. Group V contained MS media inoculated with Isolate 2. Group VI included Culture flask with MS media supplemented aqueous extracts of leaves of Azadirachta indica (1 $\mathrm{mg} / \mathrm{ml}$ ) and an inoculum of Isolate 2. Group VII had a flask with MS media supplemented with methanolic extract and inoculum of Isolate 2 . A piece of callus was placed in each flask of different groups and its growth and development of contamination were observed for $20 \mathrm{~d}$.

Table 1: Supplementation of aqueous and methanolic extract of leaf of Azadirachta indica to control bacterial contamination

\begin{tabular}{llllll}
\hline Groups & $\begin{array}{l}\text { Volume of MS } \\
\text { media }\end{array}$ & $\begin{array}{l}\text { Volume of aqueous extract of leaves } \\
\text { of } \text { Azadirachta indica }\end{array}$ & $\begin{array}{l}\text { Volume of methanolic extract of } \\
\text { leaves of } \text { Azadirachta indica }\end{array}$ & $\begin{array}{l}\text { Volume of } \\
\text { Isolate 1 }\end{array}$ & $\begin{array}{l}\text { Volume of } \\
\text { Isolate } 2\end{array}$ \\
\hline I & $30 \mathrm{ml}$ & nil & nil & nil & nil \\
II & $30 \mathrm{ml}$ & nil & nil & $0.1 \mathrm{ml}$ & $\mathrm{nil}$ \\
III & $30 \mathrm{ml}$ & $0.03 \mathrm{ml}$ & nil & $0.1 \mathrm{ml}$ & $\mathrm{nil}$ \\
IV & $30 \mathrm{ml}$ & nil & $0.03 \mathrm{ml}$ & $0.1 \mathrm{ml}$ & $\mathrm{nl}$ \\
V & $30 \mathrm{ml}$ & nil & nil & nil & $0.1 \mathrm{ml}$ \\
VI & $30 \mathrm{ml}$ & $0.03 \mathrm{ml}$ & nil & nil & $0.1 \mathrm{ml}$ \\
VII & $30 \mathrm{ml}$ & nil & $0.03 \mathrm{ml}$ & nil & nil \\
\hline
\end{tabular}




\section{Statistical evaluation}

Statistical comparisons were performed using Microsoft Excel, 2007. To assure the accuracy of the experimental data, each experiment was performed in triplicate and the result was expressed as mean \pm standard deviation of three replications.

\section{RESULTS}

Bacterial contamination was found associated with the cultured plant material of Bacopa monneira. Cloudy appearance in callus and MS media was taken as an indicator of contamination as shown in fig. 1. Bacterial Isolates 1 and 2 were isolated and identified by gram staining and biochemical method (table 2). These two isolates were found to be gram negative rods as shown in fig. 2. Biochemical characterization has revealed the positive results of Voges proskauer, triple sugar iron agar, nitrite reduction and catalase in the Isolate 1, whereas in Isolate 2 it has shown the positive results of citrate, urease, nitrite reduction, catalase and starch hydrolysis (table 2).

By using $16 \mathrm{~S}$ rRNA gene sequence analysis, a gram-negative bacterium Isolate 1 and 2 were identified. There sequences have been submitted to NCBI-GenBank and their accession number has been achieved. Isolate 1 found to be Enterobacter cloacae (Accession number KU350623) and Isolate 2 was found to be Myroides odoratimimus (Accession number KU382740). The phylogenetic tree was formed by using Phylogeny. fr (http://www.phylogeny.fr/simple_phylogeny.cgi) (fig. 3 and 4).

Antibiotic sensitivity of Isolate 1 and 2 was studied against various antibiotics like streptomycin, cefotaxime, gentamicin, amphotericin, amoxicillin, dapsone, erythromycin, chloroamphenicol, ampicillin and rifampicin. Isolate 1 was found to be resistant to amphotericin, amoxicillin, dapsone, erythromycin, chloroamphenicol and ampicillin. Isolate 2 was resistant to streptomycin, dapsone and ampicillin. But none of the Isolates was found to be resistant to carbapenem group (Tricarcillin clavulanic acid, Aztreonam, Imipenem and Meropenem) of antibiotics (table 3). These results infer that these isolates have the property of multi-drug resistance. Adding antibiotic to the culture media is one strategy to control the bacterial contamination. But adding plant extracts with proven antimicrobial activity could be a promising strategy. This concept was tried for the first time to control the contamination in in vitro culture of Bacopa monneira by adding aqueous and methanolic extracts of leaves of Azadirachta indica to MS media. Effect of treatment of media with the respective extracts of leaves of Azadirachta indica has been observed for the growth of Bacopa callus inoculated with contamination. The present work was an initial effort in the field of plant tissue culture to control the contamination associated with in vitro cultures of the plant using herbal extract. Experimental setup included 7 groups. Group I included control MS media without any extract supplementation. Group II was MS media inoculated with Isolate 1 one without any supplementation. Group III included Culture flask with MS media supplemented with aqueous extract of leaves of Azadirachta indica $(1 \mathrm{mg} / \mathrm{ml})+$ Isolate 1 . Group IV had a flask with MS media supplemented with methanolic extract of leaves of Azadirachta indica+inoculated with Isolate 1. Group V contained MS media inoculated with Isolate 2 (negative control). Group VI included Culture flask with MS media supplemented aqueous extract of leaves of Azadirachta indica $(1 \mathrm{mg} / \mathrm{ml})+$ Isolate 2. Group VII had a flask with MS media supplemented with methanolic extract of leaves of Azadirachta indica and inoculated with Isolate 2. A piece of callus was placed in a flask of each group and its growth and contamination were observed for $20 \mathrm{~d}$. Contamination of Isolate 2 was observed to be controlled by the aqueous and methanolic extract of leaves of Azadirachta indica and callus was found to be growing to give leaflets (fig. 6). Whereas the contamination due to Isolate 1 was not controlled by aqueous and methanolic extract of leaves of Azadirachta indica. Callus in flask II and III did not show the differentiation and presence of leaflets (fig. 5). Results showed the MDR strain of Isolate I was not controlled by an aqueous and methanolic extract of leaves of Azadirachta indica, while Isolate 2 can be controlled by the same extract.

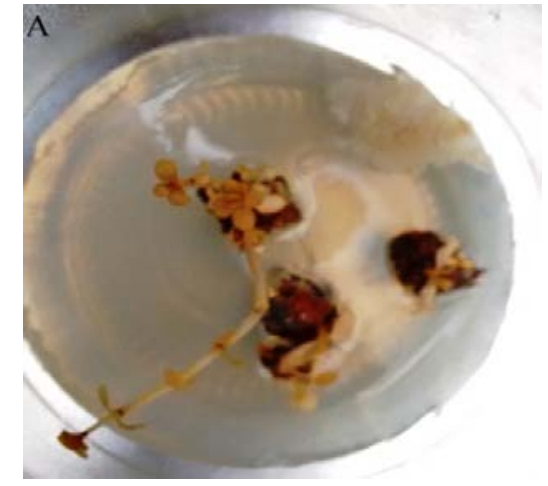

Fig. 1: Bacterial contamination around shoot base in the MS agar media. Bacterial contamination appeared after $20 \mathrm{~d}$ of inoculation
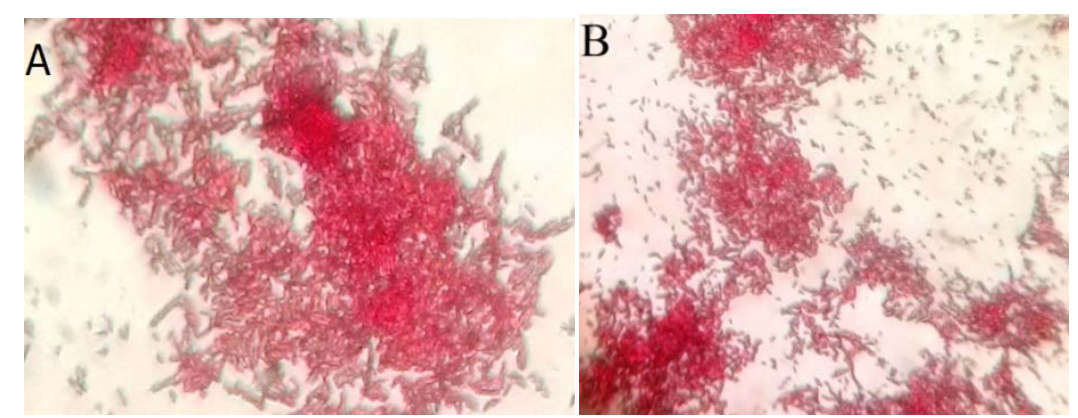

Fig. 2: Gram staining of isolates 1 (A) and isolate 2 (B) showing Gram-negative rod shaped bacteria

Table 2: The morphological and biochemical characterization of bacterial isolates

\begin{tabular}{lll}
\hline Bacteria (Morphological/biochemical test) & Isolate 1 & Isolate 2 \\
\hline Gram staining & Negative & Negative \\
Shape & Rod & Rod \\
Indole & Negative & Negative \\
Methyl red & Negative & Negative \\
Voges-Proskauer & Positive & Negative \\
Citrate & Negative, Gas production (Bubble was found) & Positive \\
Urease & Negative & Positive \\
Triple sugar iron agar & Positive & Negative \\
Nitrite reduction & Positive & Positive \\
Catalase & Positive & Positive \\
Starch hydrolysis & Negative & Positive \\
\hline
\end{tabular}


Table 3: Antimicrobial activity of different drugs against isolate 1 and 2

\begin{tabular}{lll}
\hline Bacteria & Isolate 1 & Isolate 2 \\
\hline Antibiotic & Zone of inhibition (mm) & Zone of inhibition (mm) \\
Amphotericin b (25 mcg) & $25 \pm 2.82$ & 0 \\
Streptomycin $(25 \mathrm{mcg})$ & 0 & $24.667 \pm 2.33$ \\
Amoxicillin $(20 \mathrm{mcg})$ & $25 \pm 1.41$ & 0 \\
Cefotaxime $(30 \mathrm{mcg})$ & $26.5 \pm 3.53$ & $24.667 \pm 3.44$ \\
Gentamicine $(10 \mathrm{mcg})$ & 33 & $26.667 \pm 1.03$ \\
Dapsone $(10 \mathrm{mcg})$ & 0 & 0 \\
Erythromycin $(15 \mathrm{mcg})$ & $17.5 \pm 0.70$ & 0 \\
Chloroamphenicol $(25 \mathrm{mcg})$ & $43 \pm 4.24$ & 0 \\
Ampicillin (10 mcg) & 0 & 0 \\
Rifampicin (10 mcg) & $23.5 \pm 2.12$ & $23.33 \pm 1.63$ \\
Tricarcillin calvulanic acid $(10 \mathrm{mcg})$ & 15 & 21 \\
Aztreonam (30 mcg) & 28 & 23 \\
Imipenem (10 mcg) & 26 & 26 \\
Meropenem (10 mcg) & 31 & 24 \\
\hline
\end{tabular}

$\mathrm{n}=6$; Values are expressed as mean \pm SD.

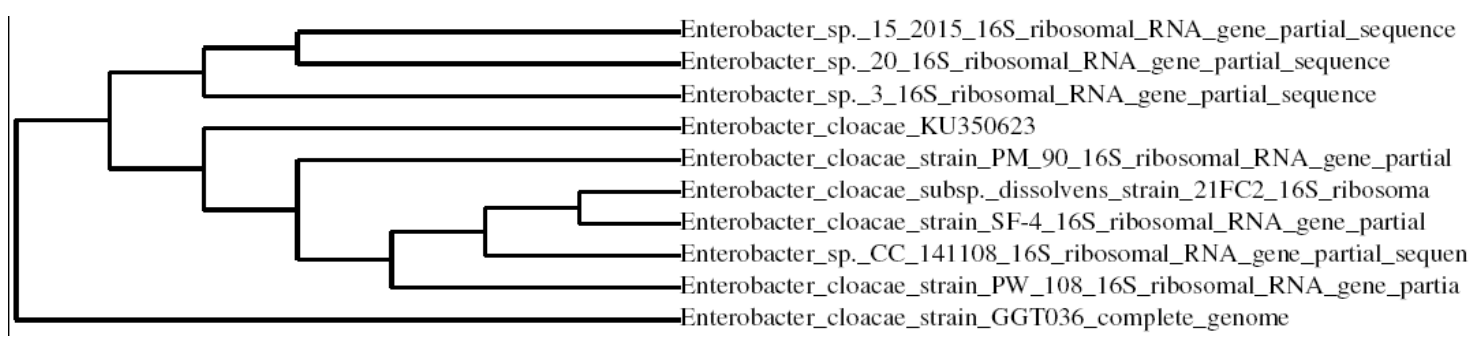

Fig. 3: Neighbour-joining phylogenetic tree based on $16 \mathrm{~S}$ rRNA gene sequence of Enterobacter cloacae (KU350623)

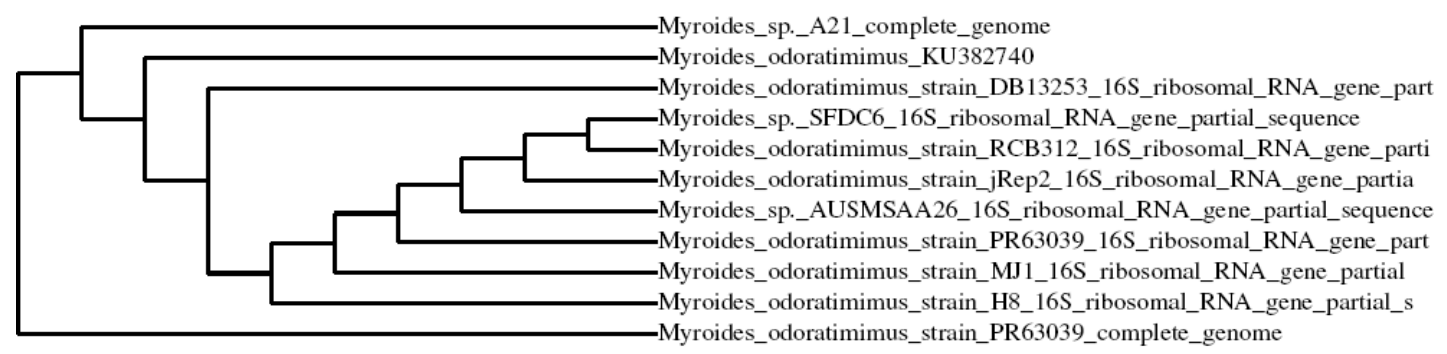

Fig. 4: Neighbour-joining phylogenetic tree based on $16 \mathrm{~S}$ rRNA gene sequence of Myroides odoratimimus (KU382740)

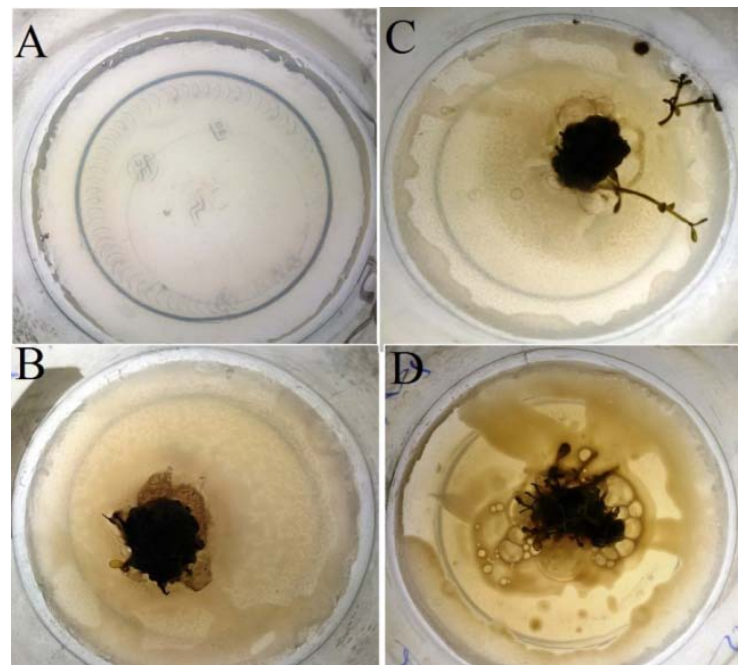

Fig. 5: Treatment of media with aqueous and methanol extract of leaves of Azadirachta indica against inoculated Isolate 1, with callus, where (A) Control MS media (group I), (B) MS

Media+Isolate I, (C) MS Media+Isolate 1+aqueous extract of leaves of Azadirachta indica and (D) MS Media+Isolate 1+methanol extract of leaves of Azadirachta indica
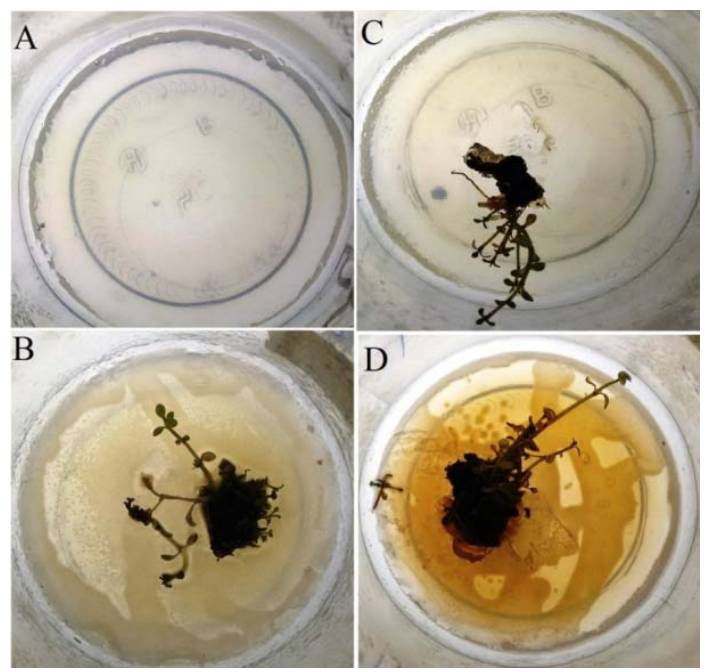

Fig. 6: Treatment of media with aqueous and methanol extract of leaves of Azadirachta indica against inoculated Isolate 2 with callus, where (A) Control MS media, (B) MS Media+Isolate 2 (C) MS Media+Isolate 2+Aqueous extract of leaves of Azadirachta indica and (D) MS Media+Isolate 2+Methanol extract of leaves of Azadirachta indica 


\section{DISCUSSION}

Micropropagation of the medicinal plant by tissue culturing is widely used to meet the demand of ever growing herbal and pharmaceutical industry. Conservation of genetic material of many threatened medicinal plants also involves culturing techniques. Bacopa monneira is such important medicinal plants. But microbial contamination of plant tissue culture is a common problem $[2,26,27]$ that leads to a gap between demand and production. Common bacterial contaminants are Bacillus, Pseudomonas, Staphylococcus and Lactobacillus [27]. Microbes multiply and compete with growing explants for nutrients while releasing chemicals which can alter culture environments e. g. $\mathrm{pH}$ and inhibit explants growth or cause death [28]. Most of these bacteria contaminants have been reported to cause culture mortality and the tissue necrosis reduced shoot proliferation and reduced rooting $[6,29]$. Contamination can be endogenously present in explants [30], or can be acquired from contaminated tools or working environment. The spread of bacterial contamination was caused by insufficient flaming of contaminated tools and by survival of bacteria in $96 \%$ ethanol for a few hours [31]. Microbial contamination presents a major challenge to the initiation and maintenance of viable in vitro cultures. Various sterilization methods like mercuric chloride, ethyl alcohol, and liquid bleach [32] have been used. Sterilization of laboratory instruments is carried out by autoclaving, alcohol washing, baking, radiations, flaming and fumigation, ultrasonic sonicator [4]. The inclusion of the antibiotics, like penicillin $\mathrm{G}$, streptomycin or tetracycline in the culture media proved effective in suppressing the growth of pure cultures of the bacterial contaminants [29]. Overuse of antibiotics may cause phytotoxicity, retard growth of explants also interfere with the complex culture media affecting the reproducibility of results [33]. It may also pose a threat of developing MDR strains. In the light of above discussion, we have conceptualized the idea of using natural plant extracts in media formulation to control the contamination in the in vitro callus culture of Bacopa monneira. Neem extracts have proven to contain antibiotic property $[17,18]$. Considering the well documented antibiotic and antifungal activity of neem, aqueous and alcoholic neem leaves extract at the concentration of $1 \mathrm{mg} / \mathrm{ml}$ was added in MS media. This extract has been found to control the growth of Isolate 2 (Myroides odoratimimus). The Bacopa callus was found to differentiate into a leaflet and show healthy growth when neem extracts (aqueous and methanolic) were added to MS media. Over contamination of Isolate 1 (Enterobacter cloacae) was also found to be controlled by neem extract treatment but this MDR strain was not completely eradicated by neem extract treatment.

\section{CONCLUSION}

Advances in plant tissue culture will enable rapid multiplication and sustainable use of medicinal plants to preserve natural drugs. Natural extract supplementations can one possible simple alternative strategy to control the in vitro bacterial contamination acquired during in vitro culture of Bacopa monneira. Azadirachta indica leaves extract better antimicrobial agent to use in media as a supplement for the growth of Bacopa monneira in Plant tissue culture Lab.

\section{ACKNOWLEDGEMENT}

The authors are thankful to Neelam Bhola and Dimple Sharma, Research Associate, Helix BioGenesis Pvt. Ltd., Noida and Dr. Chanderdeep Tandon, Director, Amity Institute of Biotechnology, Amity University Uttar Pradesh, and India for their continuous support and guidance.

\section{CONFLICT OF INTERESTS}

\section{Declared none}

\section{REFERENCES}

1. Sharma Y, Nagar A, Shukla S. Antimicrobial activity, phytochemical screening of Adenium obesum (Desert rose) leaf. Int J Pharma Bio Sci 2015;6:85-91.

2. Rout GR, Samantaray S, Das P. In vitro manipulation and propagation of medicinal plants. Biotechnol Adv 2000;18:91-120.

3. Staba EJ, Seabrook JEA. Laboratory culture. Plant tissue culture as a source of biochemical. CRC Press: Boca Raton; 1980. p. 1-20.
4. Sidhu Y. In vitro micropropagation of medicinal plants by tissue culture. Plymouth Student Scientist 2010;4:432-49.

5. Bhoite HA, Palshikar GS. Plant tissue culture: a review. World J Pharm Sci 2014;2:565-72.

6. Kane M. Bacterial and fungal indexing of tissue cultures; 2003. Available from http://www.hos.ufl.edu/mooreweb/Tissue Culture/class1/Bacterial\%20and\%20fungal\%20indexing\%20o f\%20tissue\%20cultures.doc. [Last accessed on 10 May 2016].

7. George EF. Plant propagation by tissue culture. Exergetics Ltd., Edington, England; 1993. p. 574.

8. Enjalric F, Carron MP, Lardet L. Contamination of primary cultures in tropical areas: the case of hevea brasiliensis. ISHS Acta Horticulture 1988;225:57-66.

9. Kunisaki JT. In vitro propagation of Anthurium andreanum Lind. Hort Sci 1980;15:508-9.

10. Chen WL, Yeh DM. Elimination of in vitro contamination, shoot multiplication, and Ex vitro rooting of aglaonema. Hortscience 2007;42:629-32.

11. Nadha HK, Salwan R, Kasana RC, Anand M, Sood A. Identification and elimination of bacterial contamination during in vitro propagation of Guadua angustifolia Kunth. Pharmacogn Mag 2012;8:93-7.

12. Mukheijee DG, Dey CD. Clinical trial on Brahmi. Int J Exp Med Sci 1966;10:5-11.

13. Gohil KJ, Patel JA. A review on Bacopa monniera: current research and future prospects. Int J Green Pharm 2010;4:1-9.

14. Bhattacharya SK, Ghosal S. Anxiolytic activity of a standardized extract of Bacopa monniera: an experimental study. Phytomed 1998;5:77-82.

15. Martis G, Rao A, Karanth KS. The neuropharmacological activity of Herpestis monniera. Fitoterapia 1992;63:399-404.

16. Vijayan VA, Helen A. Protective activity of Bacopa monniera Linn. On nicotine-induced toxicity in mice. Phytother Res 2007;21:378-81.

17. Gupta Y, Sharma D, Sharma Y. Bactericidal activity of different parts of Azadirachta indica on probiotic microbes. Asian J Pharm Clin Res 2016;9:50-3.

18. Biswas K, Chadhopadhyay, Banarjee RK, Bandhopadhyay U. Biological activities and medicinal properties of neem (Azadirachta indica), review article. Curr Sci 2002;82:1336-45.

19. Saeed AK, Junaid A. Study on the effect of neem (Azadirachta indica) leaves smoke in controlling airborne bacteria in residential premises. Curr Res Bacteriol 2008;1:64-6.

20. Talukdar A. Biosynthesis of total bacosides in the callus culture of Bacopa monnieri. L. Pennel from North-east India. Int J Curr Microbiol Appl Sci 2014;3:140-5.

21. Cappuccino JG, Sherman N. Techniques for isolation of pure culture In. Microbiology: a laboratory manual. (VI Ed.) Pearson Education, Inc. Singapore. Collee, JG, Duguid, JP, Frasee AG, Marmion BP. Published by Pearson Education (Singapore) Pte. Ltd; 1989. p. 63-6, 149-85, 428-31.

22. Hoffman, Winston. Genomic DNA extraction. Gene 1987;57:267-72.

23. Altschul SF, Gish W, Miller W, Myers EW, Lipman DJ. Basic local alignment search tool. J Mol Biol 1990;215;403-10.

24. Dereeper A, Guignon V, Blanc G, Audic S. Phylogeny. fr: robust phylogenetic analysis for the non-specialist. Nucleic Acids Res 2008;1:465-9.

25. Bauer AW, Kirby WMM, Sherris JC, Turck M. Antibiotic susceptibility testing by a standardized single disk method. Am J Clin Pathol 1966;45:493-6.

26. Leifert C, Waites WM, Nicholas JR. Bacterial contaminants of micro propagated plant cultures. J Appl Microbiol 1989;67:353-61.

27. Leifert C, Waites WM. Bacterial growth in plant tissue culture media. J Appl Bacteriol 1992;72:460-6.

28. Staba EJ, Seabrook JEA. Laboratory culture. Plant tissue culture as a source of biochemicals, CRC Press: Boca Raton; 1980. p. 1-20.

29. Odutayo OI, Oso RT, Akinyemi BO, Amusa NA. Microbial contaminants of cultured Hibiscus cannabinus and Telfaria occidentalis tissues. Afr J Biotechnol 2004;3:473-6.

30. Pierik RL. In vitro cultures of higher plants as a tool in the propagation of horticultural crops. In: Plant propagation by tissue culture. ISHA Acta Horticulturae; 1988. p. 24-8. 
31. Boxus PH, Terzi JM. Control of accidental contaminations during mass propagation. ISHS Acta Horticulturae 1988;225:190-8.

32. Singh V, Tyagi A, Chauhan PK, Kumari P, Kaushal S. Identification and prevention of bacterial contamination on explant used in plant tissue culture labs. Int J Pharm Pharm Sci 2011;3:160-3.

33. Barrett C, Cassells AC. Alterations in the growth of tissuecultured tansy (Tanacetum vulgare L.) treated with antibiotics. Plant Cell Tissue Organ Cult 1994;36:169-75.

\section{How to cite this article}

- Yash Sharma, Manish Bhardwaj, Anshita Nagar, Neeta Bhagat Isolation and characterization of MDR bacteria from in vitro culture of Bacopa monniera and supplementation of natural extracts to control bacterial contamination. Int J Pharm Pharm Sci 2016;8(11):102-107. 